\title{
Storm surge induced by extratropical cyclone Gudrun: hydrodynamic reconstruction of the event, assessment of mitigation actions and analysis of future flood risks in Pärnu, Estonia
}

\author{
Ü. Suursaar ${ }^{1} \&$ J. Sooäär ${ }^{2}$ \\ ${ }^{1}$ Estonian Marine Institute, University of Tartu, Estonia \\ ${ }^{2}$ Estonian Meteorological and Hydrological Institute, Estonia
}

\begin{abstract}
The aim of this paper is to analyse the impact of the hurricane Gudrun on the coastal environment, economy and crisis management of Estonia. The cyclone travelled across the Irish, North and Baltic Seas on 7-9 January 2005. Over the course of the storm, at least 17 people lost their lives in Nordic Countries, including one senior citizen in Pärnu, Estonia. The storm caused the new highest recorded storm surge $(275 \mathrm{~cm})$ in Pärnu Bay. Estimated losses due to wind damage and primarily due to flooding of the urban areas of Pärnu and Haapsalu reached $0.7 \%$ of the GDP in Estonia. The previous highest surge $(253 \mathrm{~cm})$ took place nearly 38 years ago and the scale and consequences of the new flooding were quite unexpected both for the population and authorities. The event received massive press coverage and activated a broad discussion, as some serious deficiencies in flood forecasting and mitigation abilities in Estonia were revealed.
\end{abstract}

Keywords: storm surges, hurricanes, sea level, return periods.

\section{Introduction}

The hurricane known as Gudrun in the Nordic Countries and Erwin in the British Isles and Central Europe crossed the Irish, North and Baltic Seas on 7-9 January 2005 causing the new highest recorded storm surge $(275 \mathrm{~cm})$ in Pärnu, Estonia. 
The impacts of the storm were most varied, beginning with the influences on marine ecological conditions and coastal processes and ending with socioeconomic and even psychological ones. It became the most influential natural disaster for recorded history in Estonia, which received even more media coverage than the Asian tsunami (on December 2004) or the New Orleanian hurricane Katrina (on August 2005) did.

The aims of the paper are (1) to present a meteorological and hydrological analysis of the event on the basis of routine observational data and hydrodynamic modelling results; (2) to analyse the actions carried out by authorities and crisis regulation committees before, during and after the event; (3) to study the trends both in the average sea level and developments in extreme values, frequencies of high sea level events and their return values on the basis of the statistical analysis of historical sea level data. A possible increase in the storm-related risks in the future is also discussed.

\section{Data sources and analysis methods}

The meteorological and hydrological overview of this article is based upon the routine data provided by the Estonian Meteorological and Hydrological Institute (EMHI). While the network of weather stations maintained by EMHI includes 23 stations equipped with MILOS-520 or MAWS-type automatic weather stations by Väisälä OY, only the stations located in West Estonia (Vilsandi, Ruhnu, Pärnu) are used here. The data sets include hourly data of sustained wind speeds, gust wind speeds and prevailing wind directions. EMHI also runs automatic tide gauge stations at Pärnu, Ristna and Narva-Jõesuu (Fig. 1). We present the hourly data from the Pärnu station, where the surge was the highest.

Analysis methods include various statistical and risk analysis methods. For the analysis of decadal changes in mean and extreme sea levels historical data from Pärnu are used. Linear trend analysis is used for detecting long-term tendencies in monthly average, minimum and maximum sea level values for 1924-2004. Hourly data from 1961-2004 are used to calculate empirical distribution functions and annual maximum analysis is used for detecting return periods for high sea level events.

\section{Meteorological properties of the storm and surge parameters}

Gudrun formed as a gradually deepening perturbation of the polar front in the afternoon of 7 January 2005 and moved fast eastward over the British Isles, Scandinavian Peninsula and Finland (Fig. 1a). Prior to the storm the air temperatures were between -1 and $+6^{\circ} \mathrm{C}$ in Pärnu, while the meteorological norm was around $-5^{\circ} \mathrm{C}$. It indicated a high energetic status of atmosphere and strong west-flow above the North Atlantic Ocean. The nadir point of $960 \mathrm{hPa}$ was reached northeast of Oslo at 20.00 GMT on 8 January 2005 [1]. According to the Saffir-Simpson classification, the cyclone reached hurricane strength based upon the maximum mean wind speed measurements both in Denmark and 
Sweden. According to the Danish Meteorological Institute (DMI), the highest wind speeds reached $34 \mathrm{~m} / \mathrm{s}$. Portions of Estonian territory also fell into the zone of the cyclone's strongest wind speeds, which is usually a few hundred kilometres right-hand (i.e. south) from the trajectory of the cyclone centre (Fig. 1a). Maximum average speeds of SW and W winds went up to $28 \mathrm{~m} / \mathrm{s}$ on the West Estonian coast and gusts reached $38 \mathrm{~m} / \mathrm{s}$ (Fig. 2a). Actual maximum wind speeds could have been even stronger as the malfunctioning equipment left gaps in several wind speed records interposed among some very high readings.
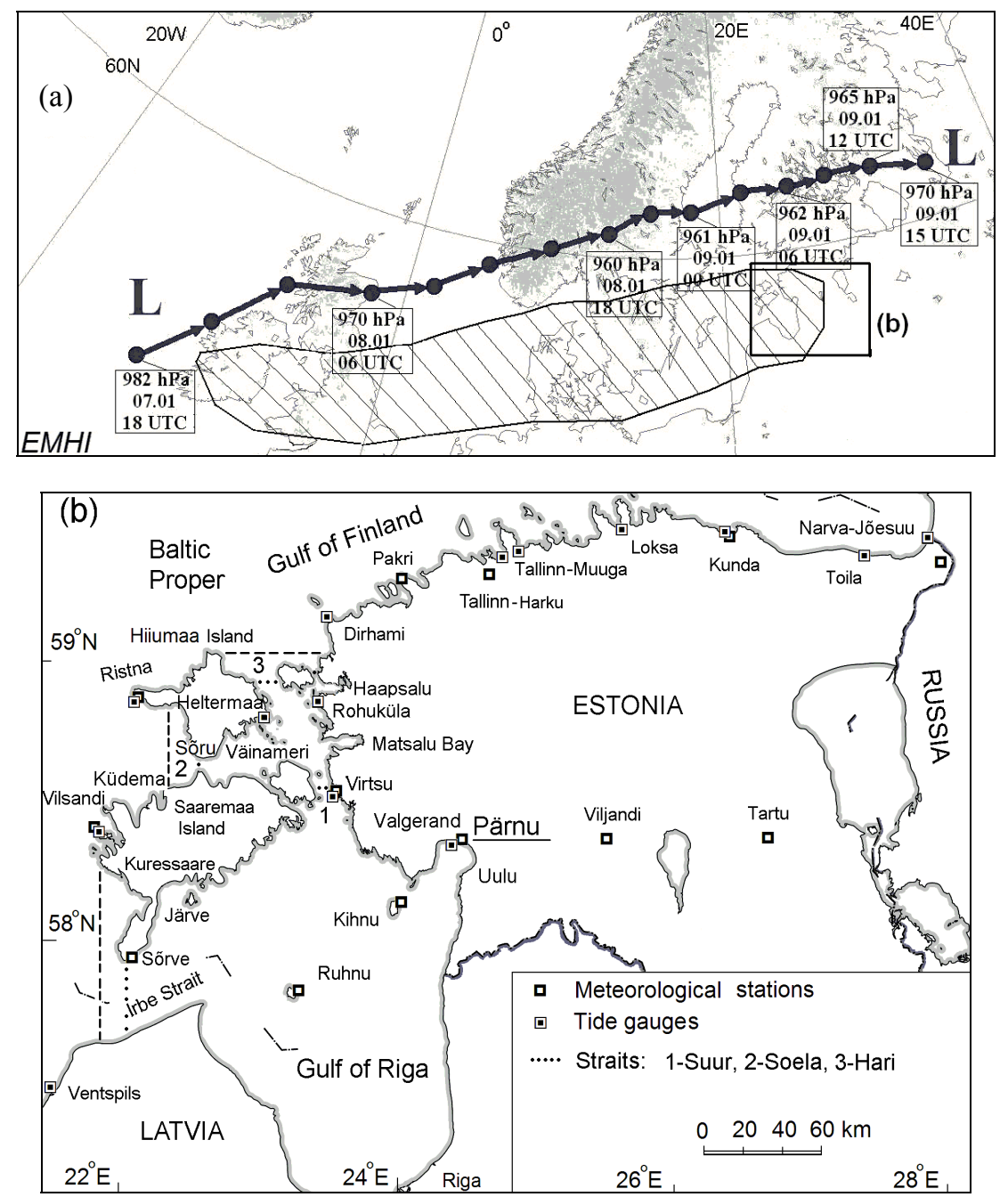

Figure 1: The trajectory of the cyclone's eye on 7-10 January 2005 [1,2] with the zone of maximum wind speeds (a); the study area (b). 

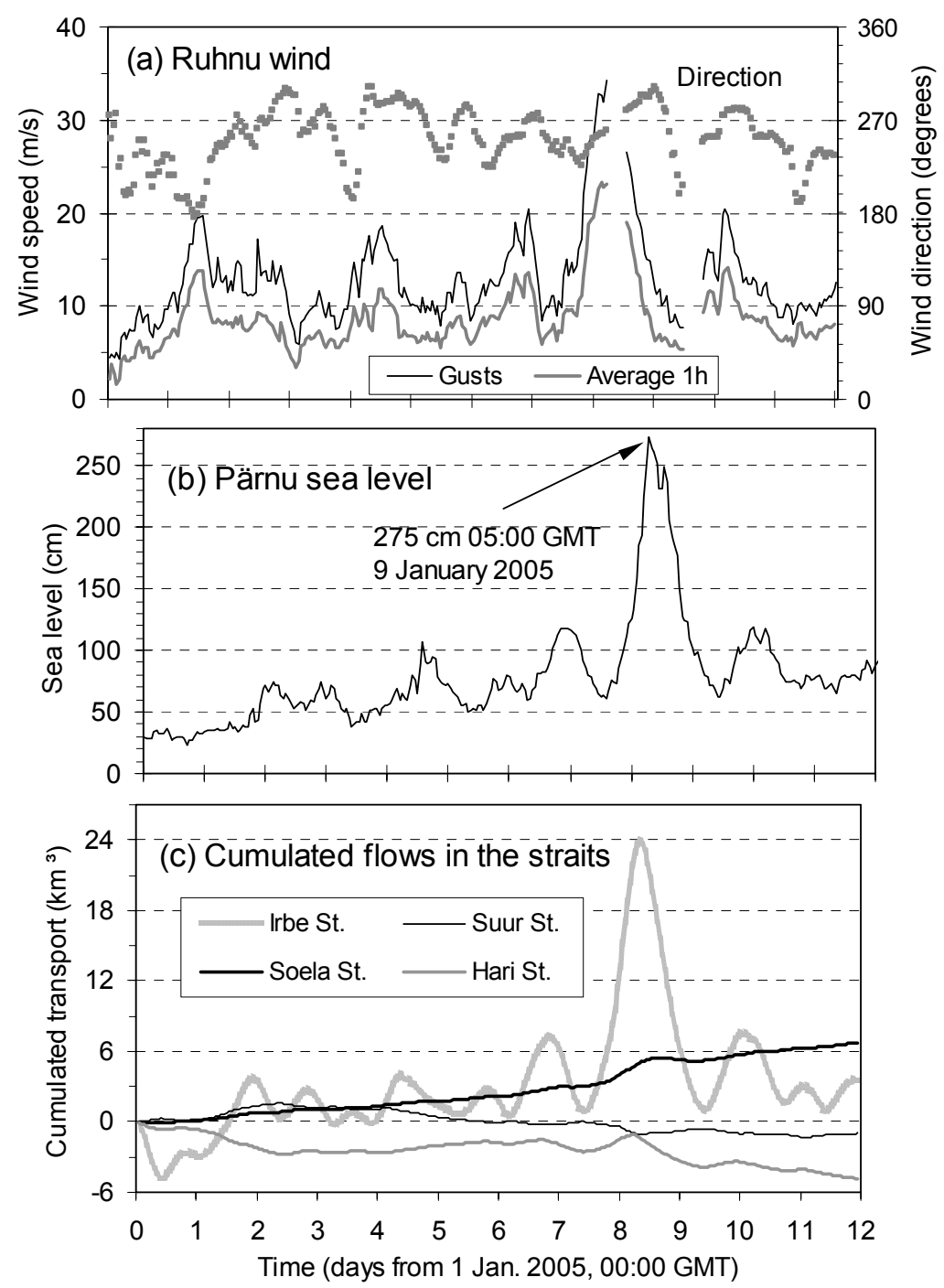

Figure 2: Hourly average wind speeds and prevailing wind directions (a), observed sea level variations in Pärnu (b) and modelled cumulative water flows through the cross-section in the straits of the Gulf of Riga and the Väinameri (see also Fig. 1b) on 1-12 January 2005.

The average Baltic Sea level had already been high since December 2004 as a result of the strong cyclonic activity that pumped the water from Kattegat through the Danish Straits into the Baltic Sea. As a result of high $(+70 \mathrm{~cm})$ background values of the Baltic Sea level, the fast travelling cyclone with a favourable trajectory yielding strong SW-W winds over Estonia, the new highest recorded storm surge occurred in Pärnu, as well as in many other locations along 
the West Estonian coast [2]. The critical sea level values are $170 \mathrm{~cm}$ in Pärnu and $140 \mathrm{~cm}$ in Haapsalu. Sea level height reached $275 \mathrm{~cm}$ at 05 GMT, 9 January 2005 according to the Pärnu mareograph data (Fig. 2b). The densely populated urban areas of Pärnu and Haapsalu were flooded for about 12 hours. New recordhigh maximum sea levels were also registered at several locations of the Estonian coastal waters. According to our hindcast hydrodynamic simulations the sea levels in popular resorts like Haapsalu and Kuressaare reached $220 \mathrm{~cm}$ $[2]$.

\section{Storm impact on coastal environment}

Gudrun influenced the Estonian coastal zone by intensification of vertical mixing processes within the sub-basins, water and matter exchange through the straits and intensification of coastal geomorphic processes as a result of the high sea level, strong currents and wave swash. According to hindcast simulations the wind driven current speeds probably reached $240 \mathrm{~cm} / \mathrm{s}$ in straits and $95 \mathrm{~cm} / \mathrm{s}$ along the open coasts [2]. During the one day at the peak of the hurricane, the Irbe Strait contributed nearly $24 \mathrm{~km}^{3}$ of fresh water to the Gulf of Riga. The smaller sub-basin of Väinameri $\left(10 \mathrm{~km}^{3}\right)$ was nearly entirely flushed through (Fig. 2c). On the other hand, some secondary pollution due to the resuspension from eutrophied bottom sediments occurred in some shallow coastal areas, like in the bays of Matsalu, Haapsalu and Pärnu.

The strong impact on coastal geomorphology was evident already from the first days of the event. Damages to harbours and beach facilities were reported both by the press and authorities. Changes in coastline position and beach profiles were studied in situ by several research programmes (national research projects, INTERREGIII Astra) during the 2005 [3,4]. It appeared that the storm caused significantly larger changes to the depositional shores than the cumulative effects of ordinary conditions, including "ordinary storms" over the preceding 10-15 year period. At the study site of Kelba (on Saaremaa Island) the spit of crystalline pebble elongated by $75 \mathrm{~m}$. The eastern side of the Sõrve spit has receded by $2-8 \mathrm{~m}$ due to erosion, while the western side has advanced by 2 $10 \mathrm{~m}$ due to accumulation. The beach ridges of gravel and pebble in the Küdema spit $[3,5]$ became steeper and a higher, the crest of the youngest and highest ridge has shifted by $10 \mathrm{~m}$ landwards. On sandy beaches at Kiipsaare the relatively low coastal scarp receded by $10-20 \mathrm{~m}$ and up to $5 \mathrm{~m}$ high Järve scarp receded $5 \mathrm{~m}$. Sand dunes were destroyed in several locations including the beaches of Tallinn and Pärnu. The $2 \mathrm{~m}$ high coastal scarp at Valgerand and Uulu beaches, both near Pärnu, turned active and were eroded [4].

\section{Humanitarian and economic consequences of the storm}

The temporary coastline recession of about $1 \mathrm{~km}$ in Pärnu caused the flooding of urban areas including large SPAs like "Tervis", "Estonia" and "Sõprus". 775 houses with 5097 inhabitants in Pärnu and 159 houses in Haapsalu were affected by the flood. 294 cars were damaged either by flood or fallen trees. Due to 
severe weather and flooding 600 people were evacuated (400 in Pärnu), 14 needed hospital treatment and one senior citizen perished in Pärnu. Altogether $15 \%$ of the households had power cuts, including $100 \%$ of the households in Hiiumaa, $78 \%$ in Saaremaa and $64 \%$ in the Pärnu county $[2,4]$. According to the Ministry of Finance of the Estonian Government, as well as the information published in the press, the total direct damage caused by the storm was 48 million EUR (28 million EUR in the private sector and 20 million in the public sector), which comprises $0.64 \%$ of the country's annual GDP.

About 1.1 million cubic meters of forest had been broken. One should bear in mind, however, that the listed losses apply only to Estonia (population 1.4 million). Losses at least of comparable magnitudes apply to Latvia (pop. 2.4 million), Lithuania (pop. 3.7 million), Sweden (pop. 8.8 million), Denmark (pop. 5.3 million), and other affected countries.

\section{Analysis of actions taken before and during the storm}

Warning of the approach of a cyclone with wind speeds up to $30 \mathrm{~m} / \mathrm{s}$ was issued to EMHI's web-site about 1.5 days prior to its onset to Estonia and official storm-wind warnings were repeated via several channels of mass-media [2]. As EMHI carried no responsibility for marine prognoses, no early warning systems for sea level existed and information about $2.4 \mathrm{~m}$ high surge risk forecasted by DMI was intermediated by individual scientists in media [6]. However, people mostly did not realise the meaning of such sea level rise at all. At least during its onset, the scale and consequences of the flooding were unexpected both for the population and authorities and in many cases people behaved inadequately.

The Government Crisis Management Committee and local crisis management committees in Pärnu and Haapsalu gathered for the first time in the evening of 8 January and again on 9 January at $2 \mathrm{am}$, while the sea level has reached $170 \mathrm{~cm}$ and the further rise appeared to be inevitable. The actions taken onward were quite adequate and in time. Rescue Board reacted to 406 emergency calls. The national Defence League, border guards, policemen and Estonian Defence Forces helped to evacuate people. As the storm and flooding lasted less than one day, the people were soon allowed to return to their properties. After the storm a committee for assessing the damages and hazard mitigation was founded on the order of the Prime Minister. Institutional activities were analysed and revision of crisis regulation systems began.

\section{Aftermath and lessons learned}

First of all, it appeared that the advance storm forecast was given in time, but an adequate official marine forecast missed altogether in January 2005. EMHI earned further criticism after overreacting with storm surge warnings on 10 January and 14 November 2005, while the sea level did not actually exceed 150 $\mathrm{cm}$ in Pärnu. As the result, the once closed Department of Marine Prognoses is to be restored in EMHI in 2006. Crisis website (www.kriis.ee) was opened and rearrangement in the warning system were started. The system consists of 
detection, management and response subsystems. It was also found, that exchange of information between relevant institutions should be improved, both specific legislation to strengthen the crisis regulation as well as territorial planning legislation needs to be improved, update of ministries and counties crisis plans should be carried out, public awareness should be educated, etc. For example, as previous surge with nearly comparable height $(253 \mathrm{~cm}$ on 18 October 1967) took place 38 years ago, some previous building standards and planning legislative acts were discontinued due to the changes in political and economical courses. Apparently, some common sense got lost as well. While centuries old buildings on high basements suffered little from Gudrun, numerous new-rise blocks appeared to be within a reach of even less than $200 \mathrm{~cm}$ sea level rise. Risk map showing coastline contours for $1.5,2.5$ and $3.5 \mathrm{~m}$ sea level rise was published (Fig. 3). It was also included as a free poster to an issue of the local newspaper. Even construction of protective dams in Pärnu Bay similar to those in Netherlands was proposed. Altogether the storm event originated a broad discussion in the whole community and initiated a number of positive changes.

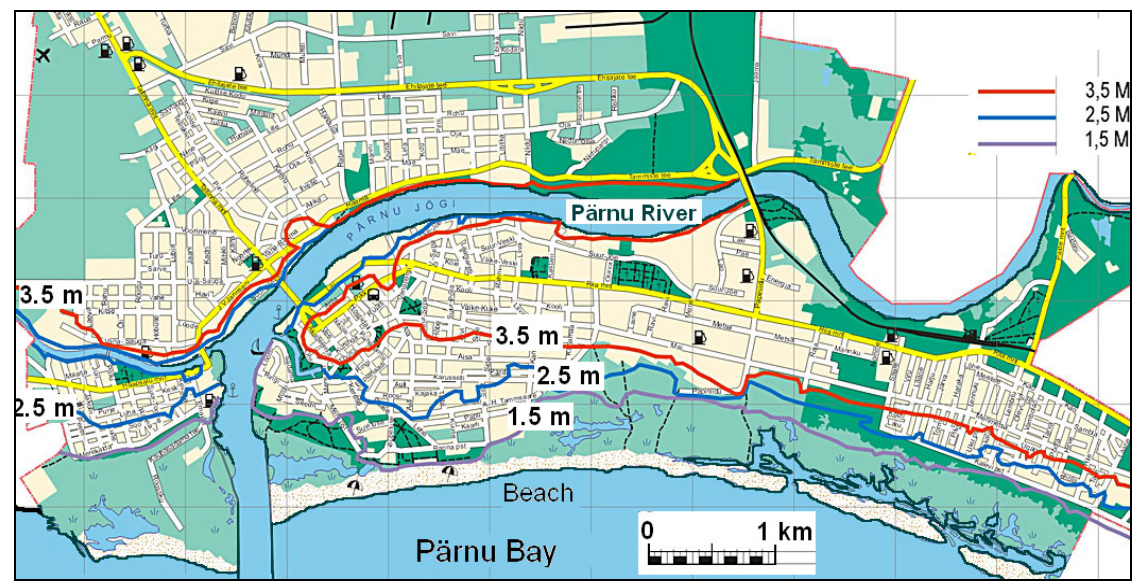

Figure 3: The areas of potential inundation in Pärnu City in case of 1.5, 2.5 and $3.5 \mathrm{~m}$ sea level rise.

\section{Future storm-related flood risks in Pärnu}

Both average and maximum sea levels have significant positive trends for the period of 1924-2005 in Pärnu (Fig. 4). Due to regional earth's crust isostatic uplift, which is $1.5 \mathrm{~mm} / \mathrm{yr}$ in Pärnu, the sea level ought to be decreased with the rate of similar magnitude. This decrease is roughly compensated by the global sea level rise, which is currently $1-2 \mathrm{~mm} / \mathrm{yr}$, but even then an additional local sea level rise component of about $1 \mathrm{~mm} / \mathrm{yr}$ appears [7]. The latter mainly applies for windward section of the Baltic Sea due to the increase in wintertime wind 
speed and storminess, which is also in good agreement with similar tendencies in winter NAO-index $[8,9,10]$.

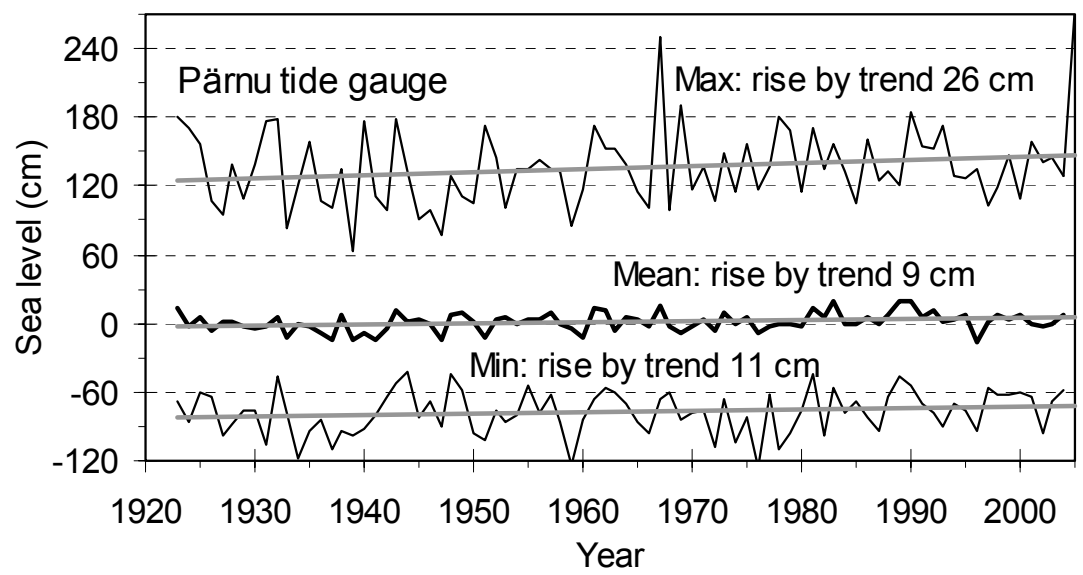

Figure 4: Decadal variations in extreme and mean sea level at Pärnu.

The rise rate in maximum sea level is even $4-5 \mathrm{~mm} / \mathrm{yr}$ in Pärnu (Fig. 4). Increase in storminess above North Europe and trends towards higher storm surges levels are recently reported by many researchers $[8,10]$.

Sea level variability in Pärnu is rather large $(400 \mathrm{~cm})$ for nearly tideless location. Analysis of empirical probability distributions of hourly data showed that the curve of 1981-2000 has shifted towards higher values, when compared with the earlier periods (e.g. 1961-1980). While the main bulk of the data can be successfully fitted with some theoretical (e.g. lognormal) distribution, there is just a handful $(0.04 \%)$ of data from two events, which appear as outliers or catastrophic events (Fig. 5a). Also no maximum values distributions (e.g. Gumbel-type distributions, Fig. 5b) can match these two highest storm surges of $253 \mathrm{~cm}$ and $275 \mathrm{~cm}$, having theoretical recurrence periods as much as 500-1000 years. The data set can be compared with the gust wind speed record that includes both normal storm-winds and data from occasional tornados [11], or the sea level data set including rare tsunami events. Nevertheless, the Pärnu surges were produced by "normal" storms, meaning that the Pärnu Bay is somewhat special among the vast majority of Baltic tide gauges. Due to its morphometric features the windward-located Pärnu Bay has large amplification (Green's) factor for surge waves [12]. As the Pärnu surge height is proportional to the wind speed (blowing from direction $220^{\circ}$ ) in the power of 2.4 [2,7], co-occurrence of some meteorological and hydrological factors is required. When the most "effective" wind direction, $30 \mathrm{~m} / \mathrm{s}$ sustained wind speed and high $(50-100 \mathrm{~cm})$ initial background sea level combine, even up to $300-350 \mathrm{~cm}$ surges are hydrodynamically and meteorologically allowed in the Pärnu Bay [2]. Projected global and regional mean sea level rise components, as well as ongoing intensification of storms additionally favour such events in the future $[8,10]$. 

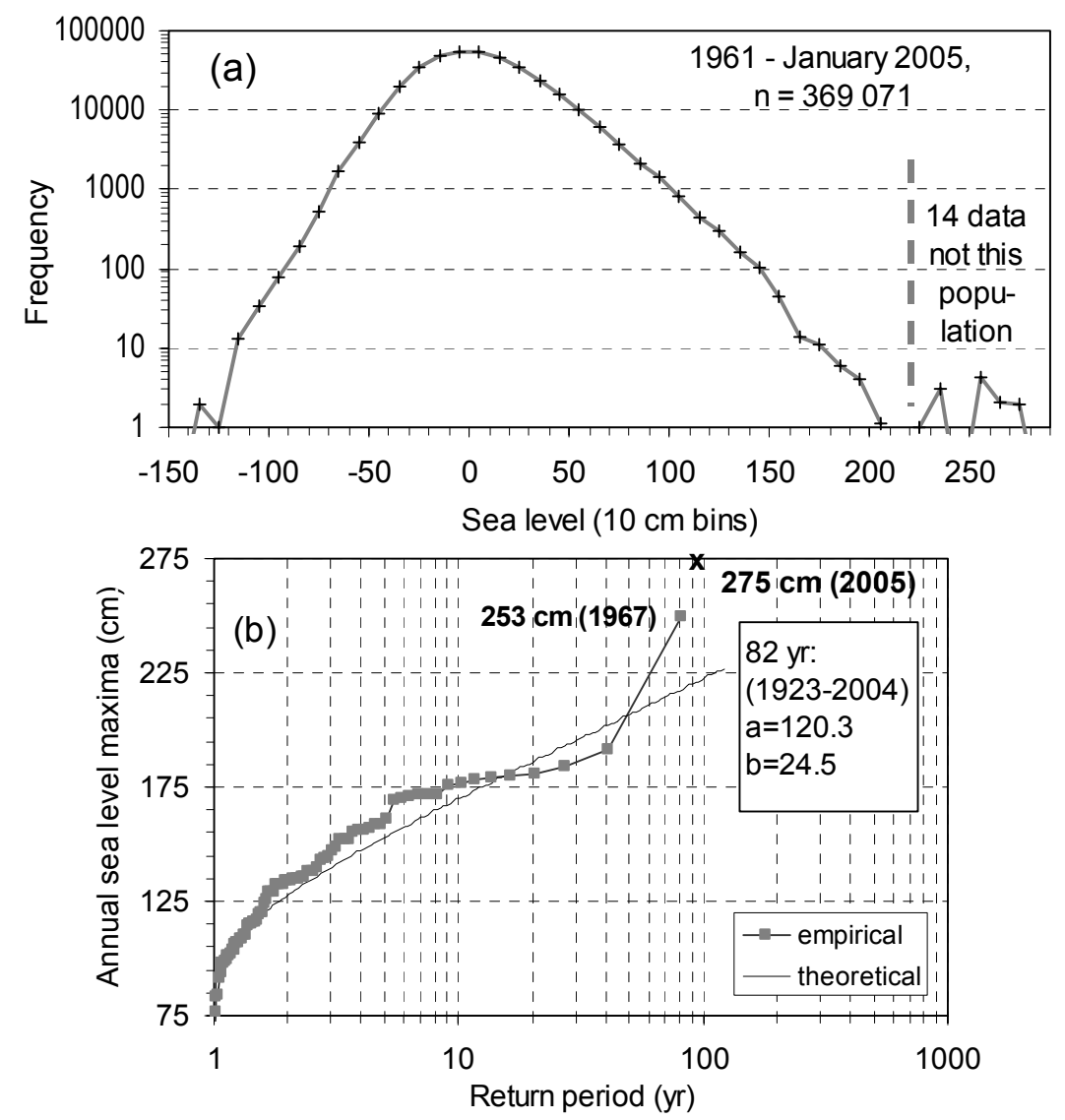

Figure 5: Empirical frequency distribution of Pärnu hourly sea level data in $10 \mathrm{~cm}$ bins. Note that logarithmic ordinate-axis emphasises tail areas (a). Return periods based on annual maximum level data in Pärnu together with theoretical Gumbel distribution (a-mode, bscale) curve (b).

\section{Conclusions}

The cyclone Gudrun on 8-9 January 2005 resulted in the new highest recorded storm surge in Pärnu $(275 \mathrm{~cm})$ and losses that reached $0.7 \%$ of Estonia's GDP. It became the most influential natural disaster in Estonia in about a century. The event activated a broad discussion, as it revealed some serious deficiencies in flood risk forecasting and mitigation abilities. However, rise in storm-related risks in the future is foreseen due to climate change. In Pärnu Bay the statistical fit of both frequency distributions of hourly data from the period of 1961-2004 and maximum values distributions for 1923-2005 does not match the two highest storm surge values of $253 \mathrm{~cm}$ and $275 \mathrm{~cm}$. In statistical sense they appear as catastrophes and their expected maximum parameters could be estimated on the basis of hydrodynamic modelling study instead. 


\section{Acknowledgements}

The study was supported by the ESF grant projects No. 5763 and 5929.

\section{References}

[1] Carpenter, G., Windstorm Erwin/ Gudrun - January 2005. Specialty Practice Briefing, 2, 2005.

[2] Suursaar, Ü., Kullas, T., Otsmann, M., Saaremäe, I., Kuik, J. \& Merilain, M., Cyclone Gudrun in January 2005 and modelling its hydrodynamic consequences in the Estonian coastal waters. Boreal Environment Research, 11, 2006 (in press).

[3] Suursaar, Ü., Tõnisson, H., Kullas, T., Orviku, K., Kont, A., Rivis, R. \& Otsmann, M., A study of hydrodynamic and coastal geomorphic processes in Küdema Bay, the Baltic Sea. Coastal Engineering VII, eds. C.A. Brebbia \& C. Cunha, WIT Press: Southampton, Boston, pp.187-196, 2005.

[4] Tõnisson, H., Orviku, K., Jaagus, J., Suursaar, Ü., Kont, A. \& Rivis, R., Coastal damages on Saaremaa Island, Estonia, caused by the extreme storm and flooding on 9 January 2005. Journal of Coastal Research, 2006 (submitted).

[5] Orviku, K., Jaagus, J., Kont, A., Ratas, U. \& Rivis, R., Increasing activity of coastal processes associated with climate change in Estonia. Journal of Coastal Research, 19, pp. 364-375, 2003.

[6] Soomere, T., Estonia got storm warning from newspapers. The Scandinavian Shipping Gazette, 4, pp. 26-29, 2005.

[7] Suursaar, Ü., Jaagus, J., \& Kullas, T., Past and future changes in sea level near the Estonian coast in relation to changes in wind climate. Boreal Environment Research, 11, 2006 (in press).

[8] Alexandersson, H., Schmidt, T., Iden, K. \& Tuomenvirta, H., Long-term variations of the storm climate over NW Europe. The Global Atmos. Ocean. Syst., 6, pp. 97-120, 1998.

[9] Andersson, H.C., Influence of long-term regional and large-scale atmospheric circulation on the Baltic Sea level. Tellus, 54A, pp. 76-88, 2002.

[10] Lowe, J.A., Gregory, J.M. \& Flather, R.A., Changes in the occurrence of storm surges around the United Kingdom under a future climate scenario using dynamic storm surge model driven by the Hadley Centre climate models. Climate Dynamics, 18, pp. 179-188, 2001.

[11] Cheng, E. \& Yeung, C., Generalized extreme gust wind speeds distributions. Journal of Wind Engineering and Industrial Aerodynamics, 90, pp. 1657-1669, 2002.

[12] Suursaar, Ü., Kullas, T. \& Otsmann, M., A model study of the sea level variations in the Gulf of Riga and the Väinameri Sea. Continental Shelf Research, 22, pp. 2001-2019, 2002. 